MH Egészségügyi Központ Sürgösségi Betegellátó Centrum ${ }^{1}$

SE ETK ${ }^{2}$ mentőtiszt hallgató, PTE ETK ${ }^{2}$ mentötiszt hallgató

$M H E K S B C^{3}$ ambulanciavezetö föorvos

\title{
Ciklohexanal okozta görcsroham a sürgösségi betegellátásban - Esetismertetés
}

\author{
Márton István', \\ Dankó Réka ${ }^{2}$, \\ Lakó Kamilla ${ }^{2}$ \\ Dr. Kiss Attila ${ }^{3}$
}

Kulcsszavak: tramadol, görcsroham, mellékhatás, farmakovigilancia, túladagolás

A cikk egy igen ritka és érdekes gyógyszermellékhatást, illetve friss nemzetközi szakirodalmi adatokat kíván megosztani. Rutinszerü gyógyszerelés kapcsán igen kevés szakember gondol a tramadol mellékhatásaira, föleg ritka mellékhatásokra. Új farmakológiai tudományág született, a famakovigilancia. Fogalma felöleli a biztonságos gyógyszeralkalmazás érdekében kifejtett tevékenységek összességét. A WHO 2002-es meghatározása szerint a famakovigilancia a gyógyszerek káros hatásaival, vagy gyógyszerrel kapcsolatos egyéb problémák észlelésével, értékelésével, megértésével és megelőzésével foglalkozó tudomány, illetve tevékenység. Szakirodalmi adatok egyértelmüen alátámasztják a ciklohexanál konvulziót okozó ritka mellékhatását, amellyel minden esetben számolnunk kell. Gyógyszergyártók honlapján megtalálható a mellékhatás bejelentésére szolgáló adatlap. Ezt az adatlapot laikusok is kitölthetik, de szakembereknek, orvosoknak sokkal nagyobb figyelmet kellene erre fordítani. Visszajelzés kulcsfontosságú a gyógyszerek biztonságos alkalmazásánakérdekében.

\section{Esetismertetés}

2011. február hónapban egy 31 éves férfi érkezett az Országos Mentőszolgálat egyik budapesti mentőállomására. Ne- héz fizikai munkavégzése közben (nehéz tárgy megemelése után) heves deréktáji fájdalma lett, nem tudott kiegyenesedni a fájdalomtól. Trauma nem érte. Élvezeti szerek hatása alatt (dohányzás, 
alkohol fogyasztás, drog) nem állt. Fizikális vizsgálattal eltérést nem észleltünk. Kardiorespiratórikusan stabil állapotú volt. Gyógyszer túlérzékenységről nem tudott. Anamnézisében gyermekkori koponyasérülést, valamint asthma bronchialét említett. Gyógyszert kizárólag alkalmanként használt Berodual-t. Vérnyomása 130/80 Hgmm, pulzusa 89/ perc, szaturációja $98 \%$, vércukor értéke $7.4 \mathrm{mmol} / \mathrm{L}$, fájdalom erőssége $10 / 8$ erősségü volt. Elmondása alapján testsúlya 80 kg volt. Vénabiztosítás G18 méretü perifériás branül behelyezésével történt, majd $100 \mathrm{mg}$ ciklohexanal (hatóanyagneve: tramadol) adása történt lassan, $\mathrm{kb}$. 4-5 perc alatt, intravénásan. Gyógyszer beadását követően a beteg hirtelen szédülésre, hányingerre kezdett panaszkodni, eszméletét elvesztette, majd tónusos görcsrohama zajlott. Azonnali oxigén terápiát indítottunk, majd antikonvulzív szerként $10 \mathrm{mg}$ diazepam adása történt intravénásan. Allergiás mellékhatást is feltételezve, $125 \mathrm{mg}$ methylprednisolon és $20 \mathrm{mg}$ chloropyramine adására került sor. EKG monitoron ritmuszavar nem volt észlelhető. Vérnyomása stabil volt. A görcsroham 3 percig tartott. 12 elvezetéses EKG készült, amelyen kóros görbe nem volt észlelhetö. A beteget tenebrosus állapotban a területileg illetékes Neurológiai Osztályra szállítottuk. Akut natív LS gerinc és koponya CT történt. Koponya CT kóros eltérést nem írt le. A LS gerinc felvételeken spondylosis és multiplex discopathia jeleit véleményezték. EEG-n kóros regisztrátumot nem észleltek. Laborjában gyulladásos markerszint emelkedés (leukocitózis, CRP-emelkedés) nem volt. Szérum ionszintek normálisak voltak. Máj és vesefunkciók jók voltak. Vizeletében kóros nem volt látható. 4 nap hoszpitalizációt követően, roham- és panaszmentesen emittálták. A kórházban töltött ápolási napok száma megegyezett a nemzetközi irodalmakban leírt adatokkal. A képalkotó és laboratóriumi vizsgálatok is hasonlóságot mutattak a szakirodalomban fellelt és alkalmazott módszerekhez képest. Szakirodalmi adatok szerint legtöbb esetben a tramadol konvulzív mellékhatását diazepam adásával szüntették meg. A készítményt gyártó gyógyszercéghez a mellékhatás bejelentésre került.

\section{Szakirodalmi összefoglaló}

Az Egyesült-Királyságban publikált egyik cikk [4] a fájdalom értékelését, az alkalmazott prehoszpitális gyógyszerelést és a paramedikusok képzését tárgyalja. A cikk ismerteti az ópiát és nem ópiát fájdalomcsillapítók hatásait, mellékhatásait. A szerzők bemutatják a különböző fájdalomskálák használatát (VAS, NRS, VRS), valamint részletezi a tramadol hatásmechanizmusát. Magyarországon a MESZK készített egy hatásköri listát, amely a szakdolgozók kompetenciáit tartalmazza [6]. Ebben a kiadványában részletezik, hogy az egészségügyi szakdolgozók milyen gyógyszereket alkalmazhatnak és adhatnak be utasításra vagy önállóan. A MESZK a hatásköri listák előkészítését országos struktúrájának megfelelően a szakmai bizottsága - az OTTB - és 11 érintett szakmai tagozatának bevonásával valósította meg. $\mathrm{Az}$ Anesthesia Essays and Researches egy törökországi esetet írt le [8]. Két napon át alkalmazott, napi $75 \mathrm{mg}$ dózisú tramadol szedését követően visszatért a klinikára, mert felesége elmondása szerint 10 perccel a gyógyszer bevétele után remegni kezdett, elvesztette az eszméletét, ami kb. 1 percig tartott és verejtékezett. A férfit befektették megfigyelésre, a tramadolt leállították, azonban aznap 
még 2 tónusos-klónusos rohama volt. Koponya CT és EEG nem mutatott neurológiai eltérést.

Teheránban 363 gyermeket vizsgáltak [5]. Mindegyik 12 évnél fiatalabb gyermekből 20-nál tapasztaltak súlyos tüneteket (átlag életkoruk 3,7 $\pm 2,9$ ). 14 esetben csökkent tudatállapotot, 3 esetben apnoét és 4 gyermekeknél hányingert, hányást észleltek. Rohamot nem észleltek egyik betegnél sem. Az átlag tramadol dózis $9,6 \pm 5,5 \mathrm{mg} / \mathrm{kg}$ volt. Az apnoe és a becsült toxikus dózis között nem volt jelenetös összefüggés. Az apnoés betegeknek naloxont adtak és nem kellett őket intubálni, azonban 2 beteg nem reagált a naloxon bólusra és eszméletlen maradt, de őket sem kellett intubálni. Az apnoés betegeknek nagyobb naloxon dózisra volt szükségük.

Hamed A. [3] a szerkesztőhöz írt levélében egy érdekes esetet mutatott be, a tramadol kiváltotta szerotonin szindrómáról (SS). Ennél a betegnél megfigyelték, hogy a tramadol önmagában képes volt SS-át okozni, amelyre jellemzők többek között a nyugtalanság, az autonóm idegrendszer rendellenességei, izom spazmusok, illetve a tudatzavar. Ezen túlmenően CPK emelkedéssel járó rhabdomyolysist, következményes veseelégtelenséget és emelkedett májenzim értékeket észleltek nála. A CPK emelkedésével járó rhabdomyolysis a tramadol hatásának ritka, de komoly szövődménye. A tünetek hasonlóak voltak BZD megvonása okozta tünetekhez.

Iráni kutatásban [2] vizsgálták a tramadol mellékhatásait, túladagolás kapcsán. A tanulmányban 150 beteg vett részt, akiket 3 csoportba soroltak és mindegyik csoportban 50 föt vettek be. Beválogatási kritérium volt: a mentális betegség és ismert függőségek hiánya, a 200 mg összdózis feletti tramadol bevétel, tramadolra pozitív vizelet teszt, markáns myoclonus jelenléte, lényeges kóros fizikális lelet hiánya, valamint normál elektrolit és laboreredmények.

$A z$ „A” csoportba sorolt betegek nem kaptak semmilyen preventív kezelést a lehetséges görcsrohamok megelőzésére. 50 főből 37 betegnek volt tónusos-klónusos rohama ( $\mathrm{p}<0,003)$, ők kezelést igényeltek és 5 esetben haláleset következett be hipoxiás-anoxiás encefalopátia miatt. A görcstevékenység az első 24 órában jelentkezett.

A „B” csoport tagjai, max. $30 \mathrm{mg}$ diazepam készítményt kaptak a görcs rohamok megelőzése céljából. 10 betegnek volt tónusos-klónusos rohama ( $\mathrm{p}<0,01)$, 7 betegnek az első 24 órában, 3-nak pedig a második 24 órában.

A „C” csoportba sorolt betegek $2 \mathrm{~g}$ magnézium-szulfátot kaptak 8 óránként a görcsrohamok megelözésének céljából. 50 emberből senkinél nem tapasztaltak rohamot, 72 óra elteltével mindenkit kiengedtek a kórházból. Valamennyi csoportban $50-50 \%$ volt a férfi-nő arány és a páciensek 16-35 év közötti fiatalok voltak. Átlagos bevett gyógyszer dózis 400 \pm 200 mg volt és nem találtak szignifikáns különbség a tramadol mennyisége és a rohamok előfordulása között ( $\mathrm{p}>0,01)$. Görcsroham 30 évnél fiatalabb betegeknél fordult elö.

Törökországban EKG elváltozásokat figyeltek meg [7] a tramadol indukálta idioszinkráziás görcsrohamok esetében. 1 év alatt 170 ember vett részt a tanulmányban. 157 beteg anamnézisében betegség nem szerepelt, 13 betegnek pedig nem volt értékelhető dokumentációja ezzel kapcsolatosan. 2 beteg anamnézisében szerepelt korábban görcsroham (1 betegnél tramadol használatot követően). Megmérték a gyógyszerbeadás és a konvulzió fellépése közti időt (150-235 perc). 68 be- 
tegnél alakult ki tachycardia, 4 betegnél sinus bradycardia. A leggyakoribb EKG eltérések a tachycardia, bradycardia, terminális S-hullám, terminális R-hullám az aVR elvezetésben, valamint T-hullám inverzió. Nem tapasztaltak LBBB-t , QT idő megnyúlást, másod, illetve harmadfokú AV blokkot.

Indiában a tapentadol és a tramadol összehasonlítását végezték [9] szívmütéten átesett betegeken. 60 beteg vett részt a vizsgálatban.

$\mathrm{Az}$ „X” csoport $50 \mathrm{mg}$ tapentadolt kapott per os napi 3 alkalommal, az „,Y" csoport $100 \mathrm{mg}$ tramadolt per os. Mind a 60 beteg kapott emellett szájon át paracetamolt 650 mg-ot, napi 4 alkalommal, valamint intravénásan fentanylt 25$50 \mu \mathrm{g} / \mathrm{kg}$-ot a mütét közben. A két csoport tagjai életkorban és testsúlyban is hasonlóak voltak. A tapentadolos csoportban a fájdalom kisebb mértékü volt a gyógyszer beadása után 3 órával, mint a tramadolos csoportban (2,68 vs. 3,91). Posztoperatív hányinger, és hányás többször jelentkezett a tramadolos csoportban. GCS értékelésnél a tapentadolos csoportban mindenki spontán nyitotta a szemét, míg a tramadolos csoportban 8 ember csak felszólításra. A tramadolos csoportban 3 betegnél BIPAP (Kétfázisú pozitív légúti nyomású lélegeztetés) lélegeztetést kellett alkalmazni, tapentadolos csoportból pedig 2 beteg esetében non-invazív maszkos lélegeztetés történt. Tramadolos csoportban 1 betegnél pszichózis alakult ki. Az Egyesült Királyságban [1] jogi kérdések merültek fel, hogy kik és milyen körülmények között alkalmazhatnak tramadolt. A cikk különböző klasszifikációkba sorolja a beadható szereket és a gyógyszerek beadására jogosultak körét. A szerzők részletesen leírják a $\mathrm{PM}$ (paramedic) és $\mathrm{RN}$ (registered nurse) által adható szerek dózisát.

\section{Felmérés}

Sürgősségi ellátásban dolgozó orvosok, mentőtisztek és szakápolók körében készült egy elemzés, amely a tramadol adásának elrendelésének gyakoriságát, valamint a mellékhatások ismeretét kívánta felmérni. $\mathrm{Az}$ „A” csoport tagjai mind szakápoló képesítésü egészségügyi szakdolgozó (50fö), akik sürgősségi osztályon triage feladatot látnak el. A feltett kérdésekre mindenki (100\%) válaszolt. „A1" csoport, 31 fo (62\%) nem szokott elrendelni tramadolt, „A2” csoport, 19 fö (38\%) igen (átlagban 50-100 mg dózisban). A válaszadók egészségügyben eltöltött munka éveinek számában szignifikáns különbség nem volt, $\mathrm{p}<0,017$. Az „A2” csoportból 48\% hányást, 39\% allergiás reakciót nevezett meg indoklásként. $6 \%$ úgy gondolta, hogy a tramadol elrendelése nem az ő feladata, $7 \%$ pedig nem tudta megindokolni. A megkérdezett szakápolók 100\%-a nem tudott a tramadol görcsrohamot okozó mellékhatásáról. „B” csoport tagjai orvosok és mentötisztek voltak. Orvosok 65\%-a hányást, 29\%-a allergiát, 6\%-a kollapszust jelölt meg olyan mellékhatásként, ami miatt nem ad tramadolt. Mentőtisztek 88\%a hányást, $6 \%$-a allergiát, $6 \%$-a görcsrohamot jelölt meg. Kollapszust nem jelöltek meg indoklásként.

\section{Következtetések}

Számos nemzetközi szakirodalom támasztotta alá a ciklohexanal (tramadol) görcsokozó mellékhatását, sokszor dózistól függetlenül. Külföldi publikációkból kiderült, hogy ezt a konvulzív mellékhatást a diazepam sikeresen megszüntette. Felmérésünkből tükröződött, hogy az orvosok, mentőtisztek és egészségügyi szakdolgozók többsége 
ezt a mellékhatást nem ismerte. Publikációnk szerette volna bemutatni a rutinszerű gyógyszeradás veszélyét és kihangsúlyozni, a gyógyszermellékhatás lejelentésének fontosságát. Mindannyiunk érdeke a biztonságos gyógyszeradás, ezért mindig gondoljunk a nem várt mellékhatások fellépésére és legyünk képesek azokat elhárítani.

\section{Irodalom}

[1] Ed, E.: Paramedics and medicines: legal considerations. Journal of Paramedic Practice, 2016, 408-415.

[2] Fares, N.: A Study of the Importance of Clonus Symptoms in Patients with Tramadol Poisoning. Journal of Toxicology, 2017, ID 2151536, 4 pages,

DOI: $10.1155 / 2017 / 2151536$

[3] Hamed, A.:Tramadol Pill Alone May Cause Serotonin Syndrome. Chinese Medical Journal, 2016, 129(7): 877-878,

DOI: $10.4103 / 0366-6999.178957$

[4] Misiołek, Hanna, Wawrzynek, J.: Analgesia Methods in the Prehospital Setting. Emergency Medical Service. Ratownictwo Medyczne, 2017, Nov. 2.

[5] Hossein, H.M.: Tramadol overdose and apnea in hospitalized children. A review of 20 cases. Research in Pharmaceutical Sciences, 2015, 10(6): 544-552.

[6] Oláh A.: Magyar Egészségügyi Szakdolgozói Kamara - Hatásköri listák. Forrás: www. meszk.hu: http://meszk.hu/info.aspx?sp=61.

[7] Peyman, H.: Electrocardiographic changes in patients with tramadol-induced. Turkish Journal of Emergency Medicine, 2016,151154, DOI: 10.1016/j.tjem.2016.08.05

[8] Serbülent, G.: Seizures associated with lowdose tramadol for chronic pain treatment. Anesthesia Essays and Researches, 2016, 10(2): 376-378,

DOI: $10.4103 / 0259-1162.177181$
[9] Srinivas, K.: Comparison of tapentadol with tramadol for analgesia after cardiac surgery. Annals of Cardiac Anaesthesia, 2015, 18(3): 352-360.

\section{Márton, Réka Dankó, Kamilla Lakó, A. Kiss MD}

\section{Tramadol-induced seizure in emergency care. Case report}

This article aims to share a very rare and interesting side effect of the drug and recent international literature. With regard to routine medication, very few experts consider the side effects of tramadol, especially rare side effects. A new pharmacological discipline was born, a pharmacovigilance. Its concept encompasses all activities undertaken for the safe use of medicines. According to the WHO 2002 definition, pharmacovigilance is the science or activity of detecting, evaluating, understanding and preventing adverse effects of drugs or other drug-related problems. Literature data clearly support the rare side effect of cyclohexanal convulsions that should always be taken into account. A list of adverse drug reactions is available on the Pharmaceutical Manufacturers website. This form can be filled in by lay people, but professionals and doctors should pay much more attention to it. Feedback is key to the safe use of medicines.

Key-words: tramadol, seizures, side effect, pharmacovigilance, overdose

Márton István 1134 Budapest, Róbert Károly krt. 44. 